\title{
Potential of Copper Electrodes in Electrocoagulation Process for Glyphosate Herbicide Removal
}

\author{
Rabiatuladawiyah Danial ${ }^{1,{ }^{*}}$, Luqman Chuah Abdullah ${ }^{2}$, and Shafreeza Sobri ${ }^{1}$ \\ ${ }^{1}$ Department of Chemical and Environmental Engineering, Faculty of Engineering, Universiti Putra \\ Malaysia, 43400 Serdang, Selangor, Malaysia \\ ${ }^{2}$ Institute of Tropical Forestry and Forest Product, Universiti Putra Malaysia, 43400 Serdang, \\ Malaysia
}

\begin{abstract}
Herbicide has been widely used since it was first marketed. Consumption of water contains glyphosate herbicide can bring adverse effects to human health. This study was intended to evaluate the performance of electrocoagulation process using copper electrodes for glyphosate removal in aqueous solution. Synthetic glyphosate powder has been diluted in deionized water. An electrocoagulation tank of $500 \mathrm{~mL}$ with two copper plates electrodes, same in dimensions were setup. The effects of continuous variables of initial glyphosate concentration, electrocoagulation time and current density, were discussed in detail. Production of copper cations showed an ability to neutralize negatively charged particles, then, encouraged to bind together to form aggregates of flocs composed of a combination of glyphosate and copper hydroxide. This study revealed that electrocoagulation process using copper electrodes is reliable by indicating $46.69 \%$ glyphosate removal. Finally, it can be concluded that electrocoagulation process using copper electrodes is efficient for glyphosate removal from aqueous environments.
\end{abstract}

\section{Introduction}

Herbicide has been widely used and application of herbicide in agriculture has further extended with increased usage for crops. In Malaysia, 172 herbicide products containing glyphosate with concentration range from $70 \%$ to $95 \%$. Glyphosate, N-(phosphonomethyl)glycine $\left(\mathrm{C}_{3} \mathrm{O}_{5} \mathrm{H}_{8} \mathrm{PN}\right)$, which is a non-selective herbicide, has a function to control plants, including grasses, broad-leaves weeds, sedges, and woody plants [1,2]. Department of Environment Malaysia reported that many types of herbicides were sold in order to improve the quantity and quality of agricultural productions. This scenario indeed caused a very large amount of herbicide used. The widespread and enormous usage of herbicide can create a potential source of pollution and poses a significant threat to contamination of both surface water and underground water. It is due to discharge of herbicide wastes from the point or diffused sources, such as agricultural runoff. Additionally, consumption of water

* Corresponding author: adawiyahdanial@yahoo.com 
contains glyphosate can bring adverse effects to human health in short-term and long-term [3]. Therefore, a treatment needs to be introduced to remove glyphosate from water.

Electrocoagulation process is susceptible to produce flocs of higher size and density, which facilitates pollutant removal by sedimentation in an aqueous solution. It was reported that electrocoagulation process has been widely applied to treat wastewater such as cutting oil emulsion wastewater [4] and textile wastewater [5]. In addition, researchers claimed that electrocoagulation process also successfully removed heavy metals from wastewater such as mercury (III) [6], phosphate [7,8], arsenic [9], fluoride [10] and antimony [11]. Electrocoagulation has advantages of minimum chemical addition and low maintenance. Electrocoagulation was selected because it has low operating cost compared to other treatments such as bioremediation, ozonation, advanced oxidation and nanofiltration. Copper was chosen as electrode plates in this study because it easy to be ionized in electrolysis system and its sludge would have high potential to be recycled.

This study handles the electrocoagulation process of a glyphosate aqueous solution in batch mode on a laboratory scale. It is mainly focused on the potential of using copper electrodes. The objective of this study is to investigate the impact of operating parameters which are initial glyphosate concentration, electrocoagulation time and current density; on the percentage removal of glyphosate. This study also comprehensively discusses the mechanism of electrocoagulation in removing glyphosate.

\section{Methodology}

Methods of this study include experimental setup and determination of glyphosate percentage removal.

\subsection{Experimental setup}

The basic setup of the electrocoagulation experiment comprised of a glass cylinder as electrocoagulation cell using a $500 \mathrm{~mL}$ beaker (Pyrex, England) with two copper electrode plates (Dingzhou Jinlong Metal Production Co. Ltd., China) of the same dimensions of (50 $\mathrm{mm} \times 50 \mathrm{~mm} \times 3 \mathrm{~mm}$ ) with a total effective surface area of $50 \mathrm{~cm}^{2}$, as anode and cathode placed in parallel. Fig. 1 shows a schematic diagram of experimental setup of this study. This laboratory scale experiment was set up in batch mode. Each batch contained $400 \mathrm{~mL}$ of feed. Glyphosate aqueous solution was prepared by dissolving white fine glyphosate powder (95\% grade, Hebei Eminent Chemical Technology Co., Ltd.) within an electrolyte. Different amounts of glyphosate powder were added to deionized water $(\mathrm{pH} 6.7 \pm 0.2$, conductivity $1.0 \mu \mathrm{S} / \mathrm{cm}$ ), depending on the required initial glyphosate concentration of 25 $\mathrm{mg} / \mathrm{L}, 50 \mathrm{mg} / \mathrm{L}, 75 \mathrm{mg} / \mathrm{L}, 100 \mathrm{mg} / \mathrm{L}$ and $125 \mathrm{mg} / \mathrm{L}$.

The conductivity of the solution was fixed by adding $400 \mathrm{mg}$ of sodium chloride $(\mathrm{NaCl})$. One plate was connected to the positive and the other plate connected to the negative outlet of a direct current (DC) power supply (HY 3003-2, Digimess, China). The DC power supply was then switched on to start the electrocoagulation process and a constant direct current was applied. The DC was adjusted to give the desired current density of $2 \mathrm{~mA} / \mathrm{cm}^{2}, 4 \mathrm{~mA} / \mathrm{cm}^{2}, 6 \mathrm{~mA} / \mathrm{cm}^{2}, 8 \mathrm{~mA} / \mathrm{cm}^{2}, 10 \mathrm{~mA} / \mathrm{cm}^{2}$ and $12 \mathrm{~mA} / \mathrm{cm}^{2}$, respectively, which is defined as the ratio of the applied direct current to the total effective surface area of the electrodes. 


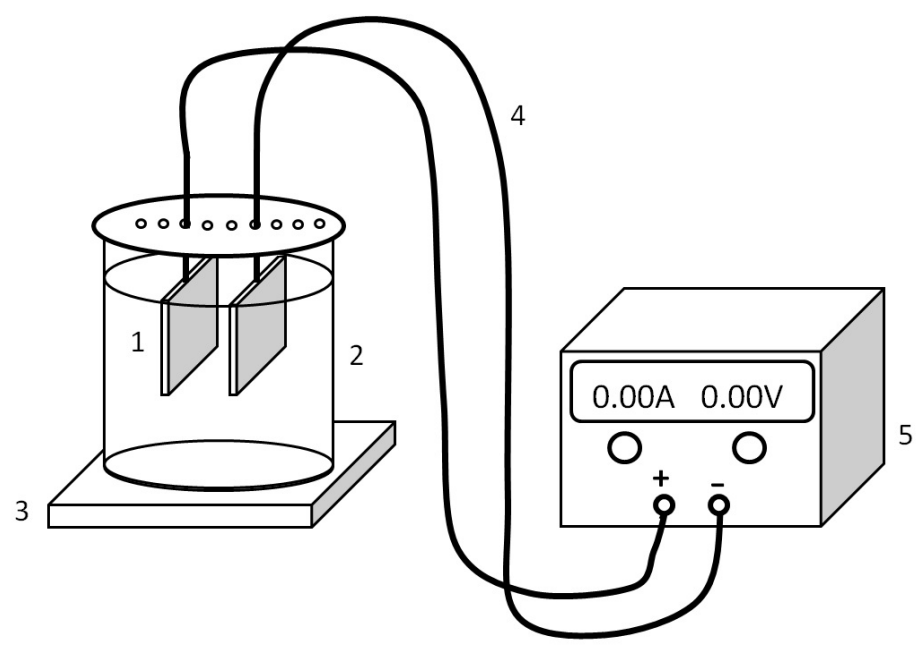

Indicators:

1. Electrodes plates (both copper)

2. Plexiglass beaker reactor (electrochemical cell)

3. Platform board

4. Wire

5. Digital DC power supply

Fig. 1. Schematic diagram of experimental setup for electrocoagulation process.

The time of electrocoagulation was varied over $10 \mathrm{~min}, 20 \mathrm{~min}, 30 \mathrm{~min}, 40 \mathrm{~min}, 50 \mathrm{~min}$, $60 \mathrm{~min}$ and $70 \mathrm{~min}$, respectively. When the DC power supply was switched off, the solution was left for 4 hours in order to allow all flocs to settle down at the bottom of the electrocoagulation cell until the treated aqueous solution exhibited as clear solution. The clear treated solution was then pumped into a filtration chamber in order to filtrate by filter paper with $0.45 \mu \mathrm{m}$ pore (Whatman, UK) and the filtrate concentration was then measured. The settled sludge was dried at $100{ }^{\circ} \mathrm{C}$ using oven (UF55, Memmert, Germany) for two hours and then was allowed to cool in a desiccator (VT144, Joan Lab, China) for one hour.

\subsection{Determination of glyphosate percentage removal}

According to the glyphosate molecular structure, glyphosate has a phosphate functional group. A chemical reaction procedure to detect phosphate in aqueous solution was adopted to determine the existence of glyphosate. A basic mathematical equation used on a regular basis in the wastewater industry is percentage of removal [12]. The glyphosate removal was measured in terms of percentage removal which is defined as;

$$
\text { Glyphosate removal }(\%)=\frac{C_{o}-C}{C_{o}} \times 100
$$

where $\mathrm{C}_{0}$ is the initial glyphosate concentration before electrocoagulation $(\mathrm{mg} / \mathrm{L})$ and $\mathrm{C}$ is the residual glyphosate concentration after sedimentation $(\mathrm{mg} / \mathrm{L})$ at a given electrocoagulation time $(\mathrm{t})$, respectively. 


\section{Mechanism of electrocoagulation}

This section discussed about mechanism of electrocoagulation process in removing glyphosate and its proposed concept. Normally, four main processes occur serially during electrocoagulation processes which are electrolytic reactions at the electrode surfaces, the formation of coagulants in the aqueous phase, adsorption of soluble or colloidal pollutants on coagulants, and removal by sedimentation or floatation [13]. Thus, glyphosate removal from this study also underwent the same processes. Electrolytic reactions at electrode surfaces are the most important process in order to form copper hydroxide as a coagulant in aqueous medium. Coagulation of glyphosate and copper hydroxide were then formed flocs and precipitated as sludge.

\subsection{Electrochemical reactions}

According to Equations (2) - (8), the oxidation and reduction process mechanisms occurred simultaneously during electrocoagulation. The electrocoagulation process using copper electrodes produced copper cations and copper hydroxide in situ as a sorbent or a coagulant to remove the glyphosate. The electrochemical reaction with copper as the electrodes was summarized as follows:

Anodic electrochemical dissolution:

Oxidation of copper ions:

$$
\mathrm{Cu}(\mathrm{s}) \rightarrow \mathrm{Cu}^{2+}(\mathrm{aq})+2 \mathrm{e}^{-}
$$

$$
\mathrm{Cu}^{2+}(\mathrm{aq})+\mathrm{H}^{+}(\mathrm{aq})+\frac{1}{4} \mathrm{O}_{2}(\mathrm{~g}) \rightarrow \mathrm{Cu}^{2+}(\mathrm{aq})+\frac{1}{2} \mathrm{H}_{2} \mathrm{O}(\mathrm{l})
$$

Hydrolysis reaction:

$$
\mathrm{Cu}^{2+}(\mathrm{aq})+2 \mathrm{H}_{2} \mathrm{O}(\mathrm{l}) \rightarrow \mathrm{Cu}(\mathrm{OH})_{2}(\mathrm{~s})+2 \mathrm{H}^{+}(\mathrm{aq})
$$

Cathodic electrochemical reaction:

$$
2 \mathrm{H}^{+}(\mathrm{aq})+2 \mathrm{e}^{-} \rightarrow \mathrm{H}_{2}(\mathrm{~g})
$$

Overall reaction:

$$
2 \mathrm{Cu}(\mathrm{s})+3 \mathrm{H}_{2} \mathrm{O}(\mathrm{l})+\frac{1}{2} \mathrm{O}_{2}(\mathrm{~g}) \rightarrow 2 \mathrm{Cu}(\mathrm{OH})_{2}(\mathrm{~s})+\mathrm{H}_{2}(\mathrm{~g})
$$

\subsection{Glyphosate bonds break out}

Glyphosate $\left(\mathrm{C}_{3} \mathrm{O}_{5} \mathrm{H}_{8} \mathrm{PN}\right)$ bonds break out by the surrounding heat that exists from electrodes in an electrocoagulation cell during electrocoagulation time was as follows.

$$
\begin{gathered}
\mathrm{C}_{3} \mathrm{H}_{8} \mathrm{NO}_{5} \mathrm{P}(\mathrm{s}) \rightarrow \mathrm{COH}_{5} \mathrm{PNO}^{-}(\mathrm{aq})+\mathrm{C}_{2} \mathrm{H}_{2} \mathrm{O}_{3}(\mathrm{l})+\mathrm{H}^{+}(\mathrm{aq}) \\
\mathrm{C}_{3} \mathrm{H}_{8} \mathrm{NO}_{5} \mathrm{P}(\mathrm{s})+\mathrm{H}_{2} \mathrm{O}(\mathrm{l})+\mathrm{H}_{2}(\mathrm{~g}) \rightarrow \mathrm{CO}_{2}(\mathrm{~g})+\mathrm{CH}_{5} \mathrm{~N}(\mathrm{l})+\mathrm{CH}_{2} \mathrm{PO}_{4}(\mathrm{l})+\frac{5}{2} \mathrm{H}_{2}(\mathrm{~g})
\end{gathered}
$$

\section{Results and discussion}

The analysis was evaluated based on the main aim which is the percentage removal of glyphosate. 


\subsection{Effect of initial glyphosate concentration}

The initial glyphosate concentration was one of the important parameters that have a high impact on the percentage removal of glyphosate [14]. Fig. 2 shows that when the initial glyphosate concentration was increased, the percentage removal of glyphosate decreased. The effect of glyphosate concentration from 0 to $125 \mathrm{mg} / \mathrm{L}$ on the removal efficiency has been investigated. It was observed that the increase in concentration for the same electrocoagulation time of $60 \mathrm{~min}$ and current density of $6 \mathrm{~mA} / \mathrm{cm}^{2}$ resulted in decreasing removal efficiency. The performance of the electrocoagulation process was slowed down when the initial glyphosate concentration approached $100 \mathrm{mg} / \mathrm{L}$. The highest percentage removal was at an initial glyphosate of $25 \mathrm{mg} / \mathrm{L}$. However, at $100 \mathrm{mg} / \mathrm{L}$ the percentage removal reached equilibrium. At $100 \mathrm{mg} / \mathrm{L}$ initial glyphosate concentration, $46.68 \%$ removal was indicated. The removal efficiency was limited by the amount of copper hydroxide produced.

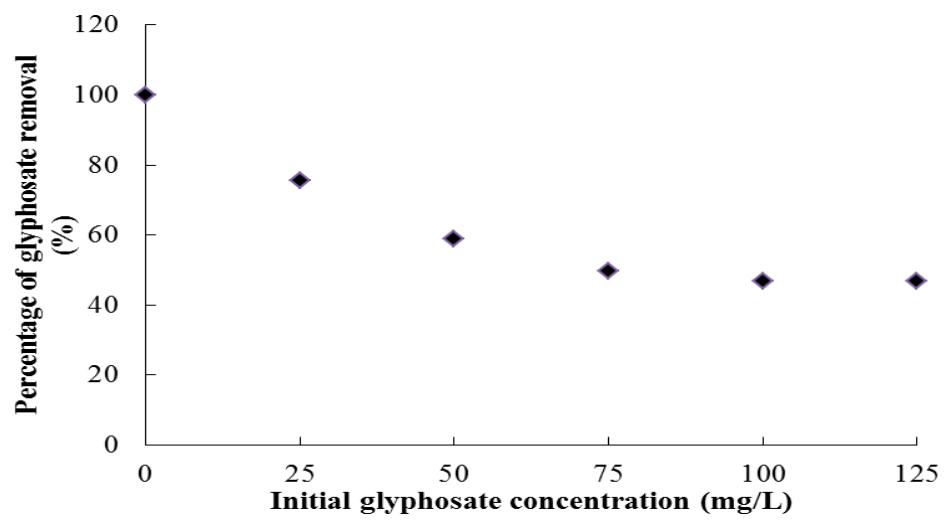

Fig. 2. Effect of initial glyphosate concentration on percentage removal of glyphosate (set up electrocoagulation condition: $60 \mathrm{~min}$ electrocoagulation time, $0.4 \mathrm{~g} \mathrm{NaCl}$ added, $6 \mathrm{~mA} / \mathrm{cm} 2$ current density, $6 \mathrm{~cm}$ distance between electrodes).

\subsection{Effect of electrocoagulation time}

The duration is the one of the most important parameters in the process of electrocoagulation. It requires an adequate period of time for the process to generate copper hydroxide, hence, to complete the coagulation of the impurities. Two reactions occur simultaneously during the electrocoagulation time. These reactions are the electrode deposition reaction and the flocs formation reaction. Both reactions occur when the current supply is turned on and end when the current is turned off. Normal process time ranges from $15 \mathrm{~min}$ to $75 \mathrm{~min}$ are for the highest possible removal of different copper ions [2]. In the present work, the electrocoagulation time used to remove glyphosate was from $10 \mathrm{~min}$ to $60 \mathrm{~min}$. Fig. 3 shows that the highest removal percentage was $46.69 \%$, with a duration of $60 \mathrm{~min}$. The percentage removals indicated in these results are in very good agreement with the results reported in the study of [14], in which removal percentage increases with an increase in electrocoagulation time. No further increase or decrease in the removal percentage was observed when the electrocoagulation time was increased beyond $60 \mathrm{~min}$. 


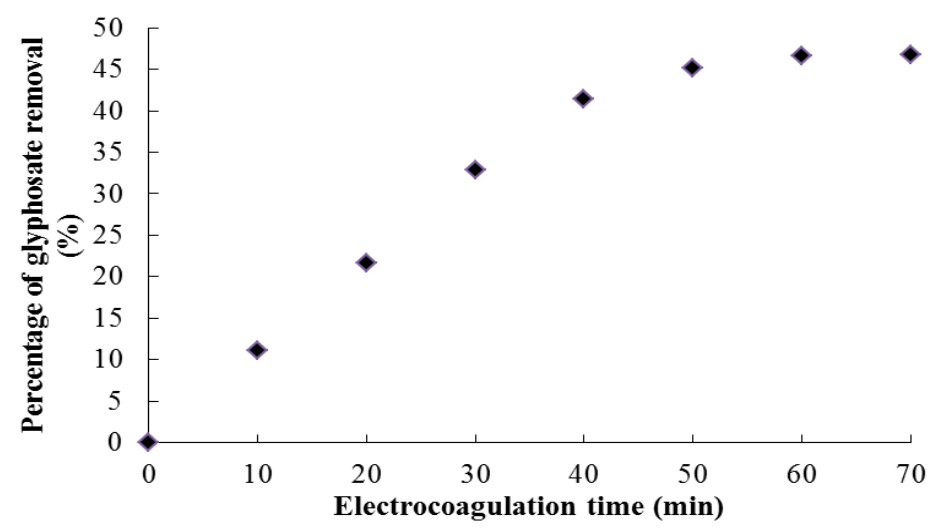

Fig. 3. Effect of electrocoagulation time on percentage removal of glyphosate (set up electrocoagulation condition: $100 \mathrm{mg} / \mathrm{L}$ initial glyphosate concentration, $0.4 \mathrm{~g} \mathrm{NaCl}$ added, 6 $\mathrm{mA} / \mathrm{cm} 2$ current density, $6 \mathrm{~cm}$ distance between electrodes).

\subsection{Effect of current density}

Current density is defined as the current applied per unit surface area of the electrode. In all electrochemical processes as well as the electrocoagulation process, the current density is an important parameter to control the reaction rate within the cell. In this study, the selected range of applied current density was from 0 to $12 \mathrm{~mA} / \mathrm{cm}^{2}$. Generally, a greater current density results in greater removal of solutes, but this may not be true beyond a certain value of current density [15-18]. However, when too large a current is used, there is a greater chance of electrical energy wasted and it is noticed when the solution became warm. Fig. 4 shows that the highest percentage removal was at $6 \mathrm{~mA} / \mathrm{cm}^{2}$ in which $46.69 \%$ removal. Direct current (DC) induces an impermeable oxide layer on the cathode due to oxidation which prevents effective current transfer between the anode and cathode. Therefore, the efficiency of the electrocoagulation process might decline when it reaches the optimum current density.

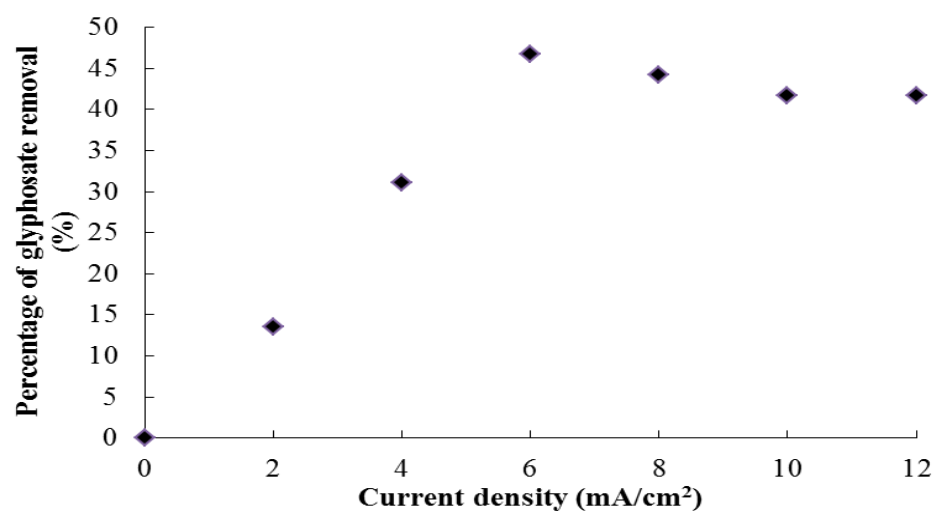

Fig. 4. Effect of current density on percentage removal of glyphosate (set up electrocoagulation condition: $60 \mathrm{~min}$ electrocoagulation time, $100 \mathrm{mg} / \mathrm{L}$ initial glyphosate concentration, $0.4 \mathrm{~g} \mathrm{NaCl}$ added, $6 \mathrm{~cm}$ distance between electrodes). 


\subsection{Sludge recovery}

The purpose of drying the sludge is to make it easy to store or to decompose. Sludge can be a big issue for the health of the environment if it is produced in large amounts and it is not able to be recycled. Several compounds detected might have a potential to be recycled. Copper sludge can be sent to a copper factory for isolation and further recovery [19]. Copper sludge can also be reused and recycled since the cost of copper mining is very high nowadays. The copper sludge can be useful since it is proposed to mix with cement to harden a concrete of building walls.

\section{Conclusion}

The electrocoagulation process using copper has been proven to be effective in removing glyphosate. Hence, by removing glyphosate, it reduces the amount of glyphosate in the water before the water is safe to be consumed. The impacts of the operating parameters on glyphosate removal, such as electrocoagulation time, initial concentration, current density, have been discussed in detail. Electrocoagulation using copper electrodes indicated a high percentage removal of glyphosate $(46.69 \%)$. Electrocoagulation is suitable for application only for a medium or small sized community compared to a huge community. Application to a large wastewater treatment plant would not be economical or cost-effective.

The authors thank Faculty of Engineering, Universiti Putra Malaysia and Ministry of Science and Technology Malaysia (MOSTI) for the grant and financial aids for this project achievement.

\section{References}

[1] S.O. Duke, S.B. Powles, Glyphosate: A once-in-a-century herbicide: Mini-review. Pest Manag. Sci., 64, 319-325 (2008)

[2] G. Chen, Electrochemical technologies in wastewater treatment. Sep. Purif. Technol., 38, 11-41 (2004)

[3] P.K. Holt, G.W. Barton and C.A. Mitchell, The future for electrocoagulation as localised water treatment technology, Chemosphere, 59, 355-367 (2005)

[4] K. Bensadok, S. Benammar, F. Lapicque and G. Nezzal, Electrocoagulation of cutting oil emulsions using aluminium plate electrodes. J. Hazard Mater., 152, 423-430 (2008)

[5] I. Zongo, A. Hama, J. Wéthé, G. Valentin, J. Leclerc, G. Paternotte and F. Lapicque, Electrocoagulation for the treatment of textile wastewaters with $\mathrm{Al}$ or Fe electrodes: Compared variations of COD levels, turbidity and absorbance. J. Hazard. Mater., 169, 70-76 (2009)

[6] C.P. Nanseu-njiki, S. Raoul, P. Claude, A. Darchen and E. Ngameni, Mercury (II) removal from water by electrocoagulation using aluminium and iron electrodes. J. Hazard. Mater., 168, 1430 1436 (2009)

[7] A. Attour, M. Touati, M. Tlili, M.B. Amor, F. Lapicque, and J. Leclerc, Influence of operating parameters on phosphate removal from water by electrocoagulation using aluminum electrodes. Sep. Purif. Technol., 123, 124-129 (2014)

[8] S. Vasudevan, J. Lakshmi, J. Jayaraj and G. Sozhan, Remediation of phosphate-contaminated water by electrocoagulation with aluminium, aluminium alloy and mild steel anodes. J. Hazard. Mater., 164, 1480-1486 (2009)

[9] E. Lacasa, P. Ca, C. Sáez, F.J. Fernández and M.A. Rodrigo, Removal of arsenic by iron and aluminium electrochemically assisted coagulation. Sep. Purif. Technol., 79, 15-19 (2011) 
[10]N. Drouiche, S. Aoudj, M. Hecini, N. Ghaffour, H. Lounici and N. Mameri, Study on the treatment of photovoltaic wastewater using electrocoagulation: Fluoride removal with aluminium electrodes-Characteristics of products. J. Hazard. Mater., 169(1-3), 65-9 (2009)

[11] J. Zhu, F. Wu, X. Pan, J. Guo and D. Wen, Removal of antimony from antimony mine flotation wastewater by electrocoagulation with aluminum electrodes. J. Envi. Sci, 23(7), 1066-1071 (2011)

[12]N. Daneshvar, A. Oladegaragoze and N. Djafarzadeh, Decolorization of basic dye solutions by electrocoagulation: an investigation of the effect of operational parameters. J. Hazard. Mater., B129(1-3), 116-22 (2006)

[13]M.F. Ni'am, F. Othman, J. Sohaili and Z. Fauzia, Electrocoagulation technique in enhancing COD and suspended solids removal to improve wastewater quality. Water Sci. Technol., 56(7), 47-53 (2007)

[14] S.A. Abdel-Gawad, A.M. Baraka, K.A. Omran and M.M. Mokhtar, Removal of some pesticides from the simulated waste water by electrocoagulation method using iron electrodes. Int. J. Electrochem. Sci., 7, 6654-6665 (2012)

[15]A. Aleboyeh, N. Daneshvar and M.B. Kasiri, Optimization of C.I. Acid Red 14 azo dye removal by electrocoagulation batch process with response surface methodology. Chem. Eng. Process.: Process Intensification, 47(5), 827-832 (2008)

[16]M. Kobya, E. Demirbas, A. Dedeli and M.T. Sensoy, Treatment of rinse water from zinc phosphate coating by batch and continuous electrocoagulation processes. J. Hazard. Mater., 173(1-3), 326-334 (2010)

[17] M. Saleem, A.A. Bukhari, M.N. Akram, Electrocoagulation for the treatment of wastewater for reuse in irrigation and plantation. J. Basic Appl. Sci., 7(1), 11-20 (2011)

[18]M. Tir and N. Moulai-Mostefa, Optimization of oil removal from oily wastewater by electrocoagulation using response surface method. J. Hazard. Mater., 158(1), 107-115 (2008)

[19] J. Rodriguez, S. Stopić and B. Friedrich, Continuous electrocoagulation treatment of wastewater from copper production. World Metall., 60(2), 81-87 (2007) 